\title{
Kroncong Orchestration of Millennial Generation
}

\author{
Victor Ganap ${ }^{\bowtie}$
}

\author{
Institut Seni Indonesia Yogyakarta, Indonesia
}

Submitted: November 22, 2018. Revised: November 4, 2019. Accepted: December 28, 2019

\begin{abstract}
Kroncong is the urban popular music of Indonesia, which some scholars suggest was brought by Portuguese in the early sixteenth century. Kroncong becomes popular across the archipelago as accompaniment in its musical genre, theatre and film. Although popular music has long been an integral part of Indonesian cultural domain, genres such as kroncong have been overlooked by music scholars. This article aims to introduce kroncong orchestration that could be performed in an updated style for incorporating repertoire from any other genres into idiomatic kroncong, that will be adopted by the millennial generation. Therefore, the reinvention of kroncong will not only be a significant contribution to scholarship on Indonesian popular music, but it will also contribute to a wider understanding of the complexities of indigenous ethnicity, political power, social class, and gender. The orchestration that will retain its rhythm pattern and vocal ornamentation, while reinforcing the strings and winds as melodic carriers.
\end{abstract}

Keywords: Kroncong; Orchestration; Millennial Generation

How to Cite: Ganap, V. (2019). Kroncong Orchestration of Millennial Generation. Harmonia: Journal of Arts Research And Education, 19(2), 117-125.

\section{INTRODUCTION}

Kroncong is the music of the urban cultural community that grew and developed in Indonesia, which was originally brought by Portuguese sailors since the sixteenth century. By the twentieth century, kroncong became popular among Indonesian urban communities, as an independent music genre and in its function as musical illustrations for theater and film. The writer began to research kroncong in a group of kroncong musicians in Tugu village North Jakarta where the community believed to have created kroncong as a combination of Portuguese fado elements from Islamic Moorish and Nusantara music. The music which was created produced a genre called Krontjong Toegoe, which has survived to this day as an example of a cultural expression that creatively combines various musical elements from the West and the East. After completing the research, the writer obtained a doctorate from Gadjah Mada University, with a dissertation title: "Krontjong Toegoe: History of The Existence of Community and Music in Tugu village, Cilincing, North Jakarta" (Ganap, 2011).

In May 2018, the writer with an American kroncong researcher named Hannah Standiford appeared in a panel discussion entitled "Reinventing Kroncong Music", which was held at the Postgraduate School of Gadjah Mada University in collaboration with the American Institute for Indonesian Studies (AIFIS) Yogyakarta. Hannah is a singer and leader of the Kroncong

\footnotetext{
Corresponding author:

E-mail: victorganap@ymail.com
} 
Grass orchestra in America, supported by American musicians in playing the kroncong instrument. She is an awardee of Fulbright Scholarship to conduct research on kroncong in Indonesia based in Surakarta. The first meeting with Hannah made the writer realized that kroncong music had developed outside Indonesia, thus this inspired him to conduct research on kroncong orchestration of millennial generation, through a research grant of Postgraduate lecturer at Gadjah Mada University in 2018.

Typically, scientific research conducted on Indonesian music is focused on gamelan music in palace traditions, such as Javanese, Sundanese, and Balinese gamelan. Although popular music has long been an integral part of the realm of Indonesian culture, still a musical genre such as kroncong is not a topic of concern for researchers in general. This situation also encourages the writer to conduct research in welcoming the possible contribution that can be made by millennial generation to kroncong music, and strives to disseminate the results of his research to international readers. It is believed that the results of this research will not only benefit Indonesian music studies, but will also contribute to a broader and more in-depth understanding of the complexity of the study of Indonesian indigenous ethnicity, the influence of cultural politics, social groups, and gender in the context of the development of kroncong music in millennial generations.

The standard musical source for Indonesian kroncong is Moresco's song, which was first written according to the transcription of Manusama (1919), in tempo moderato con amore, transcription written in high notes on the first four bars which are challenging to sing like the following example.

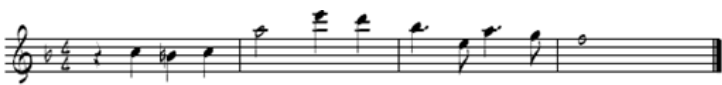

The high notes in the Moresco opening melody groove (A2-E3-D3-B2) cannot be sung by an untrained vocalist, because they are an octave higher than the notes that are common on a high compass, which demands the use of the falsetto technique, imitating Nasal vocalization, a Moor vocalist who sings without opening his mouth widely according to Islamic rules. But the Portuguese couldn't imitate the nasal vocalizations, so they replaced them with the falsetto technique. When Moresco was introduced in the East, native vocalists tended to shout to be able to reach these high notes, before they finally used nasal vocalization. Moresco's lyrics describe a melodic atmosphere according to fados, such as the Portuguese folk song despedida (farewell song) and saudade (song humming longing) that characterizes the kroncong poetry in general. The uniqueness of East and West cultural interaction is an interesting phenomenon, where the Islamic Moorish genre brought by Catholic Portuguese to the East, became popular music in Goa, Hindustani India, and was introduced by Portuguese soldiers from Goa who had become Catholic to Tugu village musicians who were Protestants before being known by the people of the city of Batavia.

In 1933, based on his experience each year watching Moresco's performances at the Krontjong Concours Jaarmarkt Night Market in Surabaja, Kusbini wrote a transcription of Moresco's songs based on his creations, which later became the standard repertoire of Indonesian kroncong songs in the form of da capo aria, using van Ophuisen's spelling poetry.

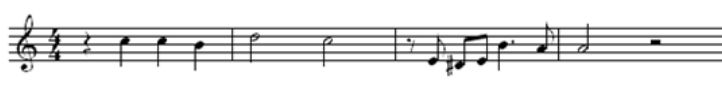

Djikalau tuan mendengarkan ini Haraplah supaja, senang di hati Ai, memetik gitar, sambil bernjanji Membikin pendengar gembira di hati

Ai, Krontjong Moritsku aku dendangkan Agar hati rindu mendjadi gembira

However, Kusbini has made history by writing Moresco as the first kroncong repertoire in the Indonesian music genre group. Kusbini created a new form called the Original Kroncong along 28 bars in the 
form of through-composed (Durch-Komponiert), interspersed with four instrumental interlude bars that appeared after the opening melody of eight bars. The original Kroncong form of the Moresco song is recognized as a generic form of Indonesian kroncong.

The orchestration of the Original Kroncong form is marked by the playing of the rasguado from the ukulele, as a rhythmic pattern of the musical accompaniment. Thus, every kroncong orchestra always uses a ukulele paired with a mandolin in playing the rhythm pattern which is played as follows.

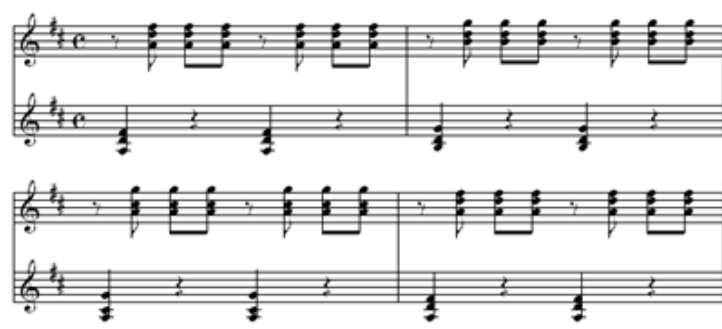

Kroncong orchestration accompanied chords from ukulele is intended to accompany the melody on the violin or flute. The melody complemented with the countermelody of the guitar through a flowing melody-like of flowing water.

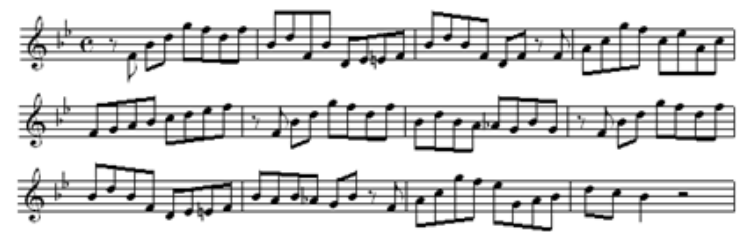

Kroncong orchestration is also characterized by playing bass on cellos and bass, playing syncopation motifs marking the characteristic pattern of kroncong.

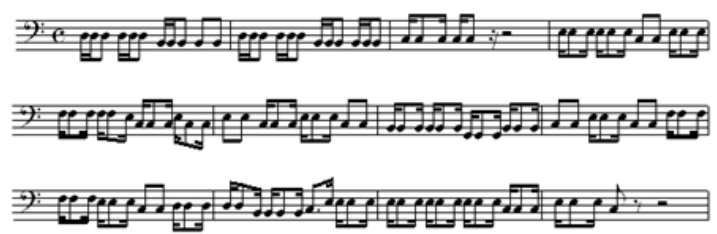

As music inherited from Moorish Islam, tambourine plays as an inseparab- le complement in the percussion section, which in its development also uses bongo Latin American music genre in an eightstroke musical play in each bar, with accentuation that fall on the seventh and eighth blows.

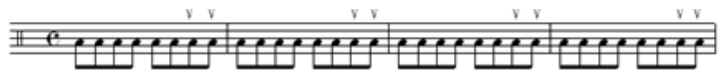

The combination of various instruments played above is the standard identity of a traditional kroncong orchestration, the meaning of which will be discussed later.

Becker (1976) acknowledged that kroncong became a category of a popular genre, sentimental songs and found throughout Indonesia. He suspected that the kroncong was introduced by the Portuguese since the sixteenth century. European-style vocalizations and simple chords as an accompaniment are usually played on the guitar, have distinguished kroncong from other popular forms of music. Kroncong was brought to eastern Indonesia, specifically Maluku, along with a guitar-like instrument owned by a Portuguese sailor, which was apparently accepted by indigenous Malukan populations. However, kroncong requires quite a long time before it can set foot firmly on the land of Java island. According to some historical sources cited, the new kroncong appeared in Java at the end of the nineteenth century, on the coast which is now Jakarta. Kroncong remains urban music, where in the twentieth century almost every village in Jakarta had its own kroncong orchestras and musicians. Becker's statement gives importance to the recognition of the legitimacy of the Portuguese element of the history of Indonesian kroncong music.

Castelo-Branco (2002) acknowledged that the kroncong guitar is an Indonesian adaptation of the Portuguese cavaquinho guitar, which in its historical journey throughout the world gained various nicknames such as the braguinha in Madeira because it came from the Braga district, the nickname of the machette in Brazil because 
it became an accompaniment instrument for Portuguese dance which was always danced during sailing, the nickname $\mathrm{cu}$ atro in the Caribbean because the guitar has only four strings, before gaining world popularity as an ukulele, which in Hawaiian means jumping fingers as a unique way of picking a string. Castelo-Branco's assertion in Grove's big dictionary justifies the existence of Indonesian kroncong guitars which are part of the chronology of the history of Portuguese cavaquinho guitars, long before ukulele reached popularity. On the other hand, Castelo-Branco gave recognition of the content of Portuguese elements in the history of Indonesian kroncong music, according to historical studies of the Maritime and Postcolonial Silk Roads.

Manusama (1919) said that the mardijkers group in Tugu village had a different identity from the mardijkers group in Batavia. Manusama believed that Tugu musicians were veterans of the Portuguese army from Goa, India who decided to stay in Tugu village. From the book Manusama Moresco sheet music that is transcribed into a song that must be performed in every Krontjong Concours festival in Batavia, is also marked by the following painting of a kroncong orchestra in Batavia and the instrumentation they used at that time.

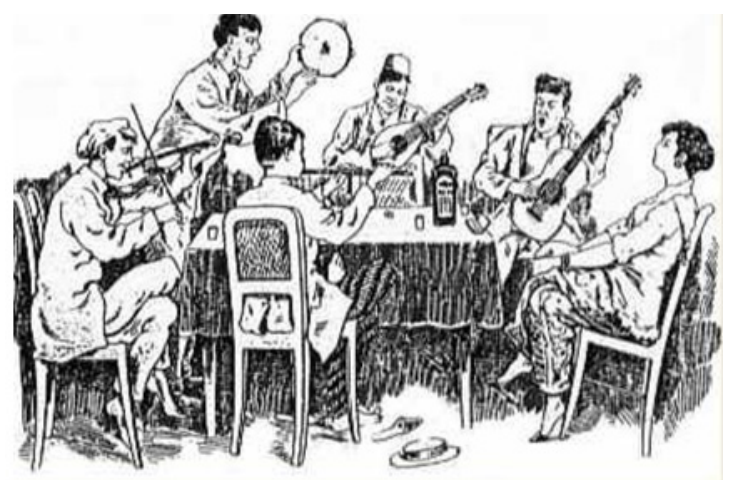

Figure 1. The first formation of kroncong players (From http:/ / rockerstarfuck.blogspot. com/2016/03/perkembangan-musik-keroncong-di.html)

Franca (1985) stated that Tugu musicians were able to achieve a high position in the bureaucracy of the Dutch East
Indies government in Batavia around the XVII and XIX centuries. They succeeded in introducing a genre of music from Cape Verde, whose pattern of rhythm became the basis of Indonesia's future kroncong music. Based on the consideration that during the colonial period of the Dutch East Indies, all Portuguese cultural heritage was suppressed, the Da França writings became rare literature in expressing various elements of Portuguese relics found throughout the archipelago. His recognition of the musician Krontjong Toegoe, who was considered to have introduced Moresco for the first time in Indonesia through the transcription he wrote in his book, was extremely important data.

Kornhauser was the only Western researcher interested in the existence of kroncong after post-independence. He went directly to conduct field research in Tugu village in 1973 and wrote the results of his research in an essay entitled "In Defense of Kroncong" published by Monash University in 1978 under the title Studies in Indonesian Music, 104-183, with editor Margaret J. Kartomi. Kornhauser acknowledged that Tugu musicians were the main actors in the history of kroncong, as living witnesses of Portuguese musical heritage in Indonesia. He believed that the Tugu village is the area from which kroncong music originated, and has been heard there since 315 years ago. Kornhauser's research results are an important source of literature on kroncong, which is never overlooked and much cited by subsequent kroncong researchers because the information provided is very comprehensive and reliable validity (Kornhauser, 1978).

Victor Ganap became the first kroncong researcher whose results were made into a doctoral dissertation at Gadjah Mada University in 2006, with the title "Krontjong Toegoe: History of the Existence of Community and Music in Tugu village, Cilincing, North Jakarta". The research proved that Tugu village musicians became the pioneers of kroncong music in Indonesia. In the journey of its long history, Tugu musicians proved their ability to sur- 
vive through Portuguese music which was passed on to them since the XVII century. Tugu musicians are minority Christian community, yet having strong primordial ties to date based on three important elements that become their identity, namely: (1) musicians who created the music genre as a generic form of Indonesian kroncong music; (2) the existence of the Tugu Church which was built in 1747, which has now been declared as a Cultural Heritage by the Government of DKI Jakarta, besides being used as worshiping infrastructure; (3) the Ikatan Keluarga Besar Tugu (IKBT) organization was founded in 1976 and became a unifying tool for them since the existence of their ancestors as residents of Tugu village in 1661 (Ganap, 2011).

Philip Yampolsky, an American researcher who has been living in Indonesia since 1980, wrote an article entitled "Three Genres of Indonesian Popular Music: Genres, Hybridity, and Globalization" published in the Asian Music journal vol. 44/2, $24-80,2013$. He stressed that the Portuguese with the support of African, Indian and Malacca traders and slaves had brought their musical influence on kroncong. Yampolsky found that the popularity of kroncong in the community was decreasing, except among generations of veterans. $\mathrm{He}$ made important contributions to the recording of kroncong music since the Dutch East Indies era in the form of the Stamboel Batavia album in 1906, the Krontjong Dasima album in 1924, and the Krontjong Concours album in 1927 which was from the Smithsonian Institution collection (Yampolsky, 2013).

\section{METHOD}

This research approach is done historically and musicologically. The historical approach is used to study the development of kroncong music orchestration from time to time, while the musicological approach is used to study the kroncong music orchestration from the aspect of music. The research is focused on kroncong music orchestration of millennial generation. The object of this research is the Kroncong Grass Orchestra in Pittsburgh, Pennsylvania, led by Hannah Standiford, the Kroncong Orchestra of Sri Gandhul Yogyakarta, led by Septi, and the Kroncong Singgih Sanjaya Orchestra. The selection of research objects is determined through a purposive method. Data collection is done by observation, interview, and documentation techniques. Data validation is done by triangulation. Data analysis of this research was carried out by analyzing interactive model data developed by Miles and Huberman which included data collection, data reduction, data verification, and data presentation as seen in the following scheme.

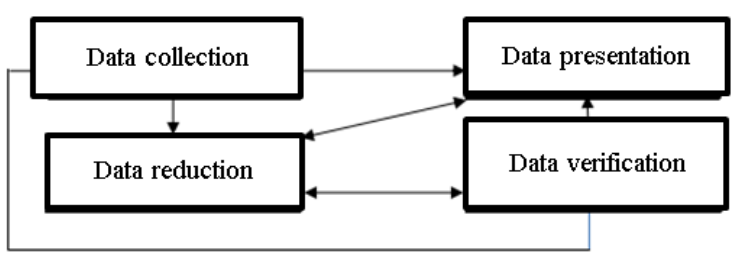

Figure 2. Scheme of Data analysis technique (Miles and Huberman, 2003)

\section{RESULTS AND DISCUSSION}

\section{Musicological Discursive}

The term of millennial generation which is the topic of this research refers to the following identities: (1) the generation born after 2000 marking the beginning of the second millennium; (2) a generation that grows up in the middle of popular culture as a result of the rock music revolution in America in 1950, which was pioneered by the appearance of Bill Haley and the Comets with their top hits song Rock Around the Clock, and was appointed to the white screen through a film titled "Blackboard Jungle"; (3) the generation that creates music as a critic of the social life of the people and rejects mass culture in the form of music commercialism; (4) a generation that has disruptive power to kroncong music according to the soul of the times.

The traditional kroncong generation is divided into three categories, namely: (1) Krontjong Concours generation; (2) Kroncong 
Bintang Radio generation, and (3) Kroncong Beat generation. The Krontjong Concours generation appeared since the Dutch East Indies was supported by NIROM (Nederlandsch Indische Radio Omroep Maatschappij), which began broadcasting since 1925 in major cities in Java including Batavia and Soerabaja. In Batavia, the kroncong musicians generally come from the Kemajoran village, where there were many kroncong groups there who performed in various markets, especially the Night Market Gambir, or as a street musician in an area that they mutually agreed on. One of the famous kroncong groups from the Kemajoran village called themselves the Krokodilen group, whose musicians consisted of Indo-Dutch, had been able to appear to attract the audience's attention on the road through their unique costumes and behaviour. After independence, the term Krokodilen then continued as the nickname "crocodile" for kroncong musicians in general.

After independence, Radio Republik Indonesia continued the Krontjong Concours tradition through the holding of the Bintang Radio Championship since 1950, including the type of kroncong songs. From Bintang Radio Championship, several superior kroncong vocalists were born, such as Masnun, Sayekti, Rita Zahara, Hetty Koes Endang, Sundari Sukoco, and many other vocalists. The Bintang Radio Championship was marked by the use of an orchestra accompaniment in the symphonic orchestration format of the Jakarta Radio Orchestra led by Isbandi, and appeared audio-visual in TVRI show since 1962.

Meanwhile, the kroncong beat generation appeared for the first time when the Tetap Segar kroncong orchestra led by Rudi Pirngadie appeared on the Indonesian performance at the New York World's Fair in 1964. The kroncong beat represented a new style that was able to incorporate the repertoire of various musical genres such as Western pop songs into idiomatic kroncong. However, although kroncong has been able to appear in international forums, it still does not receive attention for acade- mic research, due to the view of scientists that kroncong is not a pure musical genre, as well as traditional music that is worthy of research. After observing, it turns out that the actual kroncong beat style has long belonged to Tugu village musicians since the XVII century, through their multi-lingual repertoire. In this case, the kroncong beat has the potential to become one of the sources of the study of millennial kroncong, through its flexibility to adapt music from the multicultural cultural sphere. One of the positive effects of the appearance of kroncong beat in America is empirical data which shows that kroncong is starting to be recognized and even favored by the people there. One of the data that can be stated is the establishment of Kroncong Grass orchestra in Pittsburgh, Pennsylvania, led by Hannah Standiford as a vocalist while holding an ukulele as shown in the Figure 3.

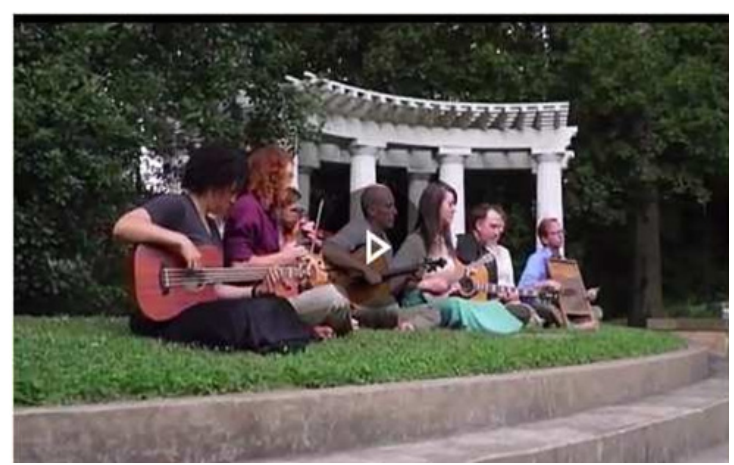

Figure 3. The performance of Rumput Kroncong Orchestra. Source: https://www. youtube.com/watch?v=tCfycrfWB_A

The Kroncong Rumput Orchestra, which plays music while sitting cross-legged on the grass, consists of 9 musicians including Hannah as a vocalist, with orchestration arrangements on violins, flutes, ukulele, guitar, cello, and brush scraped ideophone. Hannah sang the Betawi song Jali-Jali accompanied by instrument play, demonstrating the high technique that each player possesses, especially on melody-carrying instruments such as violins and flutes. Considering that the kroncong orchestration consists of Western instruments, it is not difficult for them to play it skillfully, which is usually unheard in the 
instrument playing of Indonesian kroncong musicians. Performing smoothly without reading scores, the musicians were able to accompany and improvise Jali-Jali contra-melody in eastern oriental music, even though the song did not originate from the tonality of Western culture.

The traditional kroncong generation refers to the denotation of the term kroncong as: (1) the name of a guitar musical instrument known as an ukulele adapted from Portuguese cavaquinho; (2) the name of an orchestra with its typical stringed instrumentation; (3) the name of the song form called Kroncong Asli; (4) the name of a typical rhythmic pattern of kroncong accompaniment. After entering the second millennium era, the understanding of traditional kroncong has the following connotations: (1) playing guitar in bringing contra-melody like water flowing; (2) orchestration dominated by string colours; (3) vocalist expression from the heart; (4) instrument playing which is full of ornamentation; (5) adaptive accompaniment art; (6) appearances in traditional and modern costumes; (7) reflects the new art genre or ars nova; (8) urban community music style; (9) multi-lingual repertoire; (10) Nusantara hybridity.

The traditional kroncong generation that has been stated above in entering the second millennium era has developed into a millennial generation kroncong. The denotations of the millennial generation itself according to this study are: (1) generations born after the second millennium; (2) generations that belong to mass and popular cultural civilizations; (3) the generation cradled in cyberspace through internet technology; (4) generations who have the power of disruption on established cultures.

Based on the above denotation, the identity of millennial generation orchestration can be stated as follows: (1) symphonic orchestration with expansion in the friction section and the inflatable section as the bearer of the melody; (2) kroncong beat orchestration as an accompaniment art that has multilingual flexibility; (3) aleatoric or- chestration which gives more freedom to vocalist expression in bringing minimalist, repetitive, and endless motives; (4) transgenre orchestration which enables integration with other genres such as cong-jazz, cong-rock, cong-rap, including integration in accompanying dances that have never been done before.

Data from symphonic orchestration was obtained through the Sri Gandhul kroncong orchestra Yogyakarta led by Septi whom musicians are all the female performers.

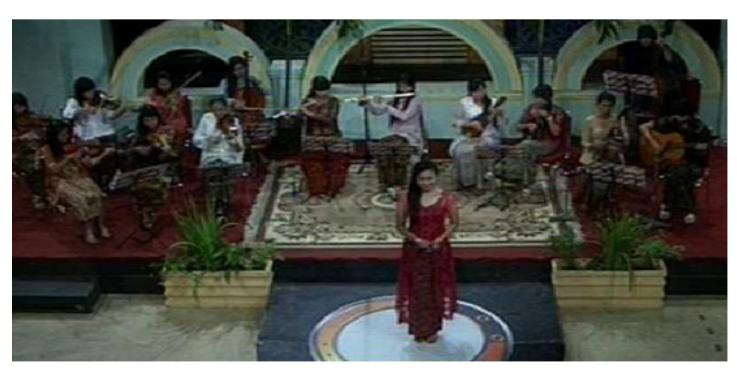

Figure 4. The performance of Sri Gandul kroncong orchestra. Source: https://www. youtube.com/watch?v=GBT6pjdVR7g

The Figure 4 shows that the Sri Gandhul kroncong orchestra consists of 14 players, including 6 violins, 2 cellos, 2 flutes, 2 ukulele, 1 guitar, and vocalist who perform kroncong in Chinese mode titled Gambang Semarang by Oei Yok Siang. Symphonic orchestration that expands in the friction section produces attractive strings and colours from two swiped and picked cellos.

Empirical symphonic orchestration data was also obtained from the Singgih Sanjaya kroncong orchestra which performed at the Independence Concert in Suryodiningratan Village, Mantrijeron Sub-district, Yogyakarta in presenting the song Ranngkaian Melati, Singgih's orchestration by expansion on the swipe section consisting of violin 1, violin 2, violin alto, cello, and bass, in accompanying the solo alto saxophone.

The millennial kroncong orchestration designed in this study is the song Bagimu Negeri by Kusbini, who is also a kroncong figure in Indonesian kroncong standards in 
the setting of Original Kroncong according to the da capo aria format, which is marked by an instrumental interlude in it. Kusbini worked on Bagimu Negeri as a hymn in moderato tempo and in the SATB homophonic arrangement. The song is one piece so it is easy to sing because it only consists of 4 musical sentences. The maestoso atmosphere that arose according to the original claim was to be designed to be shifted to a popular classic claim in the pattern of the kroncong rhythmic which is more like marcia tempo, using counter technique as the science of melody in polyphonic fabric.

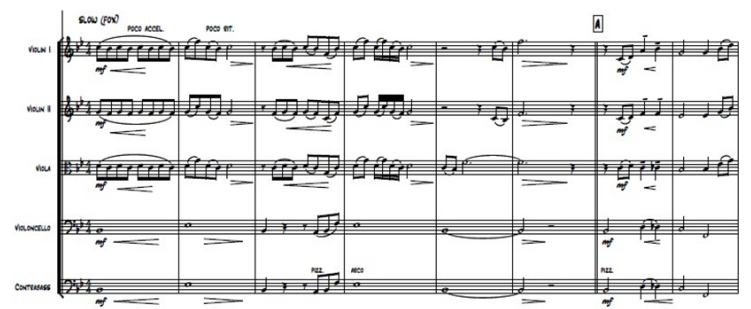

An opening presented in 4 bars was presented by the string section, especially violin 1, violin 2 and alto violin with unisono melodies, but actually functioned as a contra-melody of the main melodies of the last sentence delivered by the inflatable section consisting of flute, oboe, clarinet in $\mathrm{Bb}$, bassoon, horn in $\mathrm{F}$. The last three notes in the fermata give more freedom to end the opening and at the same time starting the song theme accompanied by the appearance of a filler on the trumpet in $\mathrm{Bb}$, accompanied by bass tones on trombone, tuba, and tympanic.

Entering the theme of the song, the string section began to play through violin 1 , violin 2 and violin alto bring the main melody, which is balanced with the contramelody of cello and bass, as can be seen from the partition score below.

Thus, millennial generation kroncong designed in this study refers to symphonic orchestration with expansion in the friction section and the metal blown section as a melody carrier, which is thickened by adding tympanic membrane colour to the percussion section, more than just the appearance of a tambourine or rebana.
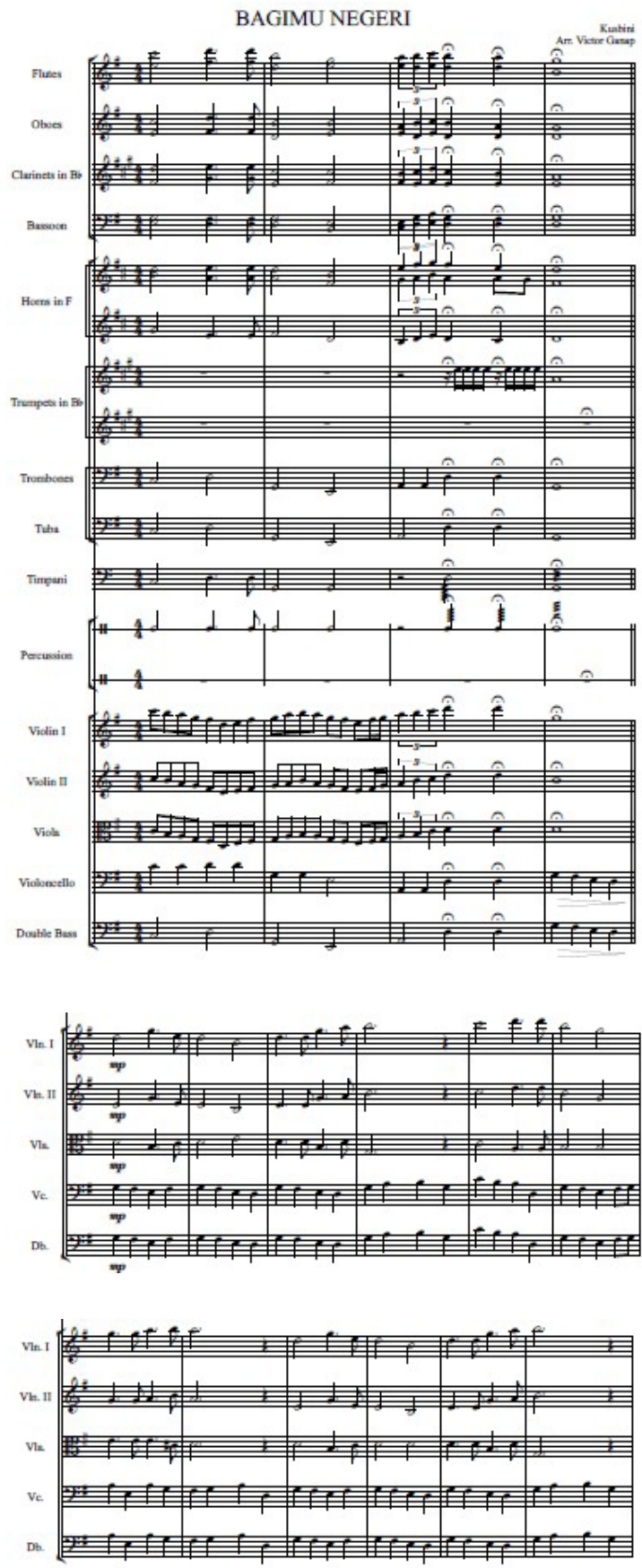

This orchestration still uses the rhythmic patterns of the ukulele 1 and ukulele 2 in the cuk and cak format, or the kroncong and mandolin formats as the generic identity of a kroncong orchestration. This orchestration is certainly designed to accompany the vocalist both in singular and choir form in unisono and in polyphonic. Nationalism-themed titles in the kroncong song have been written as Kr. Pemuda Pemudi, Kr. Bahana Pancasila,, so that the 
orchestration design of $\mathrm{Kr}$. Padamu Negeri, whose song was created by Kusbini as a kroncong figure, became an alternative to the millennial generation kroncong orchestration. This research gives hope that the development of academic kroncong will be a fundamental and sustainable policy in entering the second-millennium era.

\section{CONCLUSION}

This study concludes that the development of kroncong as millennial generation music still requires academic and creative processes that provide professional appeal for millennial generation music students. The concept of millennial generation kroncong orchestration design leads to the establishment of symphonic orchestration which is arranged academically as a basic study of the source of its cultivation. Symphonic orchestration has an advantage based on the consideration that kroncong becomes part of high culture as a contemporary experimental music that is sustainable for further researchers. Kroncong symphonic orchestration as an urban popular music is designed in the realm of high culture, which is oriented to the aesthetic beauty of music, and is not part of a mass culture oriented to commercialism.

This study explicitly did not design the kroncong beat orchestration, aleatoric orchestration, and trans-genre orchestration, because the orchestration belonged to and created the cultural sphere of the community with various social missions it carried. Since long time ago, kroncong has been proven to be able to adapt to various cultures and periods, so it is time to become an interesting material object of musicology research, moving from the formal object of the discipline of Humanities in the historical study of the Maritime Silk Roads and Postcolonial.

\section{REFERENCES}

Becker, J. (1976). Kroncong, Indonesian Popular Music. Asian Music, 8(1), 14-19.

Castelo-Branco, S. E.-S. (2002). Portugal. "Stanley Sadie, The New Grove Dictionary of Music and Musicians (Vol. 1, pp. 1044-1045). London: Macmillan.

França, A. P. D. (1985). Portuguese Influence in Indonesia. Calouste Gulbenkian Foundation.

Ganap, V. (2011). Krontjong Toegoe. Yogyakarta: Badan Penerbit Institut Seni Indonesia Yogyakarta.

Kornhauser, B. (1978). In Defence of Kroncong. Studies in Indonesian Music, 7(1), 104-183.

Miles, M. B. \& Huberman. (2003). The Qialitative Research Companiaon. USA: Sage

Manusama, A. T. (1919). Krontjong: als muziekinstrument, als melodie en als gezang. Jakarta: Boekhandel G. Kolff $\&$ Co.

Yampolsky, P. (2013). Three Genres of Indonesian Popular Music: Genres, Hybridity, and Globalization. Asian Music, 44(2), 24-80. 